\title{
A REEXAMINATION OF ANTITRUST LAW AND EXCLUSIVE TERRITORTAL GRANTS BY PATENTEES
}

\author{
MaLCOLM E. WheELRR $\dagger$
}

A patentee can employ various means to maximize the income he derives from his patented invention. One of these is the exclusive territorial assignment or license, by which the patentee divides the nation into various regions and assigns or licenses one person in each region to be the sole manufacturer, seller, or user of the invention. ${ }^{1}$ Three prominent antitrust commentators, Professors William Baxter, Donald Turner, and Gerald Gibbons, recently examined the antitrust implications of such practices, ${ }^{2}$ and each concluded that existing antitrust and patent laws should be interpreted either to proscribe exclusive territorial licenses and assignments or to strictly limit their use. ${ }^{3}$

On the other hand, the few courts that have faced the issue have concluded that existing laws permit patentees to engage in such practices. ${ }^{4}$ In apparent recognition of judicial reluctance to proscribe the creation of exclusive territories, the White House Task Force on Antitrust Policy (of which Professor Baxter was a member) has recommended that Congress eliminate exclusive assignments and licenses by amending the patent laws to require that "a patent owner who has

$\dagger$ Associate Professor of Law (designee), University of Kansas. S.B. 1966, Massachusetts Institute of Technology; J.D. 1969, Stanford University. Member, California Bar.

1 Strictly speaking, an "exclusive license" is a grant by the patentee or his assignee of some agreed immunity under the patent, coupled with a promise to exclude others from engaging in the licensed activities. The license is "exclusive" because the patentee has promised to grant no further licenses of the type enjoyed by the exclusive licensee, not because the exclusive licensee is the first or only licensee. For example, the patentee may have granted one license under his patent prior to promising a second licensee to grant no future licenses. See Western Elec. Co. v. Pacent Reproducer Corp., 42 F.2d 116, 118-19 (2d Cir. 1930); United States v. Krasnov, 143 F. Supp. 184, 200-01 (E.D. Pa. 1956); 4 A. WaLKER, Patents $\$ 381$, at 542 (2d ed. A. Deller 1965). This Article will assume for purposes of discussion the usual situation wherein an exclusive licensee is the sole licensee in a specified territory.

2 Baxter, Legal Restrictions on Exploitation of the Patent Monopoly: An Economic Analysis, 76 YALE L.J. 267, 347-52 (1966) [hereinafter cited as Baxter]; Gibbons, Domestic Territorial Restrictions in Patent Transactions and the Antitrust Laws, 34 GEO. WASH. L. REv. 893, 894-904 (1966) [hereinafter cited as Gibbons]; Turner, The Patent System and Competitive Policy, 44 N.Y.U.L. REv. 450, 469-74 (1969) [hereinafter cited as Turner].

3 See Baxter 347; Gibbons 898, 903 ; Turner 474.

4 See Brownell v. Ketcham Wire \& Mfg. Co., 211 F.2d 121, 128 (9th Cir. 1954); United States v. Parker-Rust-Proof Co., 61 F. Supp. 805, 812 (E.D. Mich. 1945); cf. United States v. General Elec. Co., 272 U.S. 476, $489-91$ (1926); Deering, Milliken \& Co. v. Temp-Resisto Corp., 160 F. Supp. 463, 480-81 (S.D.N.Y. 1958). 
granted a license with respect to his patent must license all qualified applicants on equivalent terms." 5

Thus it has been suggested that (1) existing antitrust laws can and should be interpreted to proscribe or to restrict severely the use of exclusive territorial assignments and licenses, and (2) if existing laws are not so interpreted by the courts, Congress should act to ensure that result. This Article reexamines both questions and concludes that neither the proscription nor the restrictions which have been advocated are embodied in existing laws or advisable for future legislation. As a solution to problems with exclusive grants perceived by critics, it is proposed that the patent laws be amended to permit each patentee to make one, and only one, such grant. That grant could be made for any territory and time period within the statutory seventeen year limit.

\section{The Status of Exclusive Territorial Assignments AND LICENSES UNDER EXISTING LAwS}

Section 261 of the Patent Act ${ }^{6}$ appears to authorize a patentee to make exclusive territorial assignments:

$[P]$ atents, or any interest therein, shall be assignable in law by an instrument in writing. The .. . patentee . . . may in like manner grant and convey an exclusive right under his . . patents, to the whole or any specified part of the United States. ${ }^{7}$

5 White House Task Force Report on Antitrust Policy 10 (1969) thereinafter cited as TASK FORCE REPORT]. A recent amendment proposed by Senator Scott to S. 2756, 91st Cong., 2d Sess. (1970) (reintroduced as S. 643, 92d Cong. 1st Sess. (1971)), would amend the Patent Act to permit the assignment of patent applications on the same terms as patents themselves and to allow territorial licenses, whether exclusive or nonexclusive, at the option of the patentee. This bill would clearly eliminate any possible formalistic distinction between licenses and assignments implicit in present law.

635 U.S.C. $\$ 261$ (1964).

$7 I d$. To understand fully the meaning of $\$ 261$ as originally enacted in 1836 , one must examine the law then governing the scope and validity of a patent. If state law determined the rights of the patentee, Congress might have intended $\$ 261$ to have a more limited, procedural impact than if federal law alone determined these rights.

Enacted pursuant to U.S. Const. art. I, $\$ 8$, the first Patent Act, Act of Apr. 10, 1790 , ch. 7,1 Stat. 109, clearly authorized a federal procedure for granting patents by application to the Secretary of State, the Secretary of War, and the Attorney General. Id. $\$ 1$, 1 Stat. 109-10. Its successor, Act of Feb. 21, 1793, ch. 11, 1 Stat. 318, established more than the mere mechanism by which the patent was granted. In particular, the Act opened the circuit courts of the United States to the patentee to sue for infringement "in an action on the case founded on this act . Id. \$5, 1 Stat. 322. Although jurisdiction was apparently concurrent with that of the state courts, id., the courts were to apply federal law as far as possible. The Act of Apr. 17, 1800, ch. 25, $\$ 4,2$ Stat. 38, repealed $\$ 5$ of the 1793 Act. The later act provided that the patentee or his heirs or assigns could recover for infringement "by action on the case founded on this . - act, in the circuit court of the United States, having jurisdiction thereof." Act of Apr. 17, 1800, ch. 25, 33 , 
Although in discussing the issue the courts have not always explicitly relied on section 261 to sustain exclusive territorial assignments against antitrust attacks, they have at least adverted to the statute. ${ }^{8}$ Several commentators also have relied upon section 261 for legislative approval of exclusive territorial licenses and assignments. ${ }^{9}$

Professors Baxter, Turner, and Gibbons, however, have taken a contrary position. They argue that in enacting section 261 Congress was concerned with distinguishing patent licenses from patent assignments and that Congress never considered the measure in relation to the substantive propriety of exclusive territorial grants of either nature. For this reason, and because the nation's first antitrust statute was enacted more than fifty years after the enactment of section 261 , they conclude that the validity of exclusive territorial grants should be determined solely by reference to the antitrust laws. ${ }^{10}$ Resolving the conflict between these two views of section 261 and of the Sherman Act requires an examination of the pertinent legislation from the enactment of section 261, through the passage of the Sherman Act, to the amendment of the Patent Act in 1952.

Prior to 1836 it was unclear whether a patentee could assign an exclusive territorial right to utilize his invention or whether he could only license such a right. This distinction was of some consequence.

2 Stat. 38. Any reference to concurrent jurisdiction was eliminated, further reinforcing the suggestion that federal, not state interests were at stake in patent cases.

At least one state court held that it had no jurisdiction under the 1800 Act to adjudicate an infringement action under the Patent Act, because such jurisdiction belonged exclusively to the circuit courts of the United States. See Parsons v. Barnard, 7 Johns. 143 (N.Y. Sup. Ct. Jud. 1810). Apparently, then, by 1810 judicial opinion recognized that patent rights must be determined according to federal law in federal court. See also W. Robinson, The Law of Patents \$855 (1890).

Further congressional action prior to the enactment of $\$ 261$ included a provision granting the circuit courts equity jurisdiction in patent cases in addition to that which they enjoyed in law pursuant to the 1800 Act. Act of Feb. 15, 1819, ch. 19, 3 Stat. 481. Interpreting this statute and relying on federal law and general equitable principles, a federal court sitting in New York refused to issue an injunction against an infringement, declaring that the plaintiff should maintain an action on the law side of the federal court to determine the validity of his patent. Undoubtedly, the law court would base its decision on federal rather than state principles as did the equity side. Sullivan v. Redfield, 23 F. Cas. 357 (No. 13,597) (C.C.D.N.Y. 1825). Thus Congress enacted $\$ 261$ in an atmosphere of federal control over both the substance and procedure of patent grants, and that section should be read as an integral part of a comprehensive federal policy only incidentally involving any state interest. $C f$. W. Phillts, The LAW of Patents for Inventions 380 (1837). 1954).

8 See, e.g., Brownell v. Ketcham Wire \& Mfg. Co., 211 F.2d 121, 128 (9th Cir.

9 See W. Fugate, Foreign Commerce and the Antitrust Laws 198-202 (1958); R. Nordeaus \& E. Jurow, Patent-Antitrust Law 141 (1961).

10 See Baxter 349-52, 357 (Professor Baxter, however, qualifies this conclusion by conceding that section 261 does immunize an exclusive territorial assigmment if the assignee agrees to issue licenses substantially identical to his assignment.); Gibbons 896-98; Turner 463 n.11, 474 n.21 (Professor Turner adopts Professor Baxter's analysis of $\$ 261$ rather than undertaking an independent examination of the provision.). 
An assignee could sue for infringement, grant licenses under the patent, and enjoy the benefits of owning property. But a licensee held only the contractual right to utilize the invention free from liability for infringment and ordinarily could not transfer his interest or exercise the other rights of a titleholder. ${ }^{11}$ Because of the substantial differences between assignments and licenses, Congress attempted to delineate the boundary between the two by enacting section 261 in $1836 .{ }^{12}$ In establishing this boundary Congress considered sufficiently comprehensive to warrant classification as an assignment "every grant . . . of the exclusive right . . . to make and use, and to grant to others to make and use, the thing patented within and throughout any specified part . . . of the United States." 13 The current formulation of section 261, as quoted above, ${ }^{14}$ was derived from this language.

Congress enacted the Sherman Act in $1890 . .^{15}$ Section 1 of the Act provides :

Every contract, combination in the form of trust or otherwise, or conspiracy, in restraint of trade or commerce among the several States, or with foreign nations, is declared to be illegal. ${ }^{16}$

The territorial restrictions referred to in section 261 could easily be interpreted to conflict with this general prohibition of anticompetitive practices:

A pattern of licenses or assignments which carves the United States up into geographic subdivisions and thereby confers on licensees [or assignees] a monopoly position in their respective subdivisions has obvious potential for economic harm. . .

.. [T] he less valuable the invention, the more likely it is that licensees [or assignees] will be seeking not the right to use the invention so much as a legal umbrella for market division. ${ }^{17}$

Because the Sherman Act was intended to proscribe a loosely defined class of activities which under certain circumstances would include the specific activity previously governed by section 261 , one must inquire

11 See Baxter 349-50.

12 Act of July 4, 1836, ch. 357, §11, 5 Stat. 117. This section and its successors are collectively referred to in this Article as "section 261," with notation of the version under consideration when appropriate.

$13 \mathrm{Id}$.

14 Text accompanying note 7 , supra.

15 Act of July 2, 1890, ch. 647, §1, 26 Stat. 209.

1615 U.S.C. $\$ 1$ (1964).

17 Baxter 347. See also Gibbons 903 ; Turner 471, 474. 
whether the Sherman Act's broad language should be read as an interdiction of that activity.

To this question Professors Baxter, Turner, and Gibbons have replied affirmatively, ${ }^{18}$ relying upon their narrow reading of section $261 .^{19}$ Noting that the statute was enacted to distinguish between assignments and licenses, they assert that it therefore cannot be construed as authorization for exclusive territorial licenses and assignments, and that even if valid before 1890 , such practices are contrary to the Sherman Act and hence unlawful. ${ }^{20}$ Professor Baxter concludes: "Only by amateurish literalism or cynical distortion can it be argued that $\S 261$ places a general imprimatur of legality on territorial restrictions." 21

Their thesis, however, is erroneous. First, it fails to weigh adequately implicit congressional authorization of exclusive territorial grants; second, it ignores the effect of post-Sherman Act amendments to section 261; third, it reads section 261 without reference to the broad policy of the Patent Act as a whole; and, finally, it fails to recognize the economic similarity between exclusive licenses and exclusive assignments.

Professor Baxter ${ }^{22}$ correctly notes that section 261 originally differentiated between those territorial grants which constitute assignments and those which are mere licenses, ${ }^{23}$ but he fails to recognize that this congressional expression implied an affirmation of the substantive propriety of exclusive territorial rights. Congress would have had no reason to define precisely the territorial patent interests which could be assigned had it not intended to authorize such territorial grants. ${ }^{24}$ The presence of authorizing legislation-even when the authorization is only implicit-indicates a legislative preference that cannot be treated lightly by the courts. Although a legislative "event"

18 See Baxter 349. Professors Gibbons and Turner do not advocate proscription; but they think the Sherman Act permits whatever action is needed to protect antitrust policies from the activities authorized by section 261 , and they propose severe restrictions on that basis.

19 Text accompanying note 10 sipra.

20 See Baxter 349-52, 357 (As pointed out above, note 10 supra, Baxter qualifies this conclusion as applied to assignments.); Gibbons 903; Turner 473-74.

21 Baxter 349.

22 Because Professor Baxter's analysis of $\$ 261$ is the most thorough, and for the sake of convenience, the ensuing discussion will refer to Baxter as representative of all three critics, unless otherwise indicated.

23 See Baxter 349.

24 Commentary and judicial opinions interpreting $\$ 261$ prior to the enactment of the Sherman Act assumed that territorial grants were lawful and focused on whether the grant transferred sufficient interest in the patent to constitute an assignment or merely a license. See Littlefield v. Perry, 88 U.S. (21 Wall.) 205, 219 (1874); Moore v. Marsh, 74 U.S. (7 Wall.) 515, 521 (1868); Gayler v. Wilder, 51 U.S. (10 How.) 477, 494-95 (1850); A. Walker, The Patent Laws §287 (1st ed. 1883). 
such as the Sherman Act confers broad powers upon the courts to delineate its practical scope, in exercising such powers the courts must give greater deference to activities specifically sanctioned by legislation than to activities that have never been the subject of legislation.

A greater weakness in Professor Baxter's analysis of the impact of the antitrust laws on section 261, however, is the summary treatment he accords the post-Sherman Act congressional and judicial actions regarding section 261. Congress modified section 261 three times following enactment of the Sherman Act and each time retained the language concerning exclusive territorial assignments:

[I]n 1897, the sentence making certificates of notaries prima facie evidence of execution of an assignment was added; ${ }^{\text {[25] }}$ in 1941 the section was expanded to include applications as well as patents; ${ }^{[20]}$ and in 1952 the several sentences were rearranged into their present order ${ }^{[27]} \ldots .^{28}$

On the last of these three occasions, Congress divided the subsection into two sentences, the second of which states: "The . . . patentee . . . may in like manner grant and convey an exclusive right under his . . . patents, to the whole or any specified part of the United States." 29 Even if, as Professor Baxter contends, Congress has failed to consider the economic consequences of permitting exclusive territorial grants, this repeated restatement of the assignability of exclusive territorial rights, culminating in a separate statement of the right, militates strongly against judicial proscription of such a practice under the Sherman Act.

If a statute is enacted authorizing a specific activity which could be subsumed under a prior and much broader prohibition, the authorization should prevail. Congressional reiteration and refinement of the grant of a narrow right subsequent to the enactment of a broad conflicting prohibition is equivalent to subsequent enactment of the narrower grant. Since Congress did reenact the authorization of the right to assign an exclusive territorial right after the Sherman Act, the authorization should control. Clearly, Congress cannot be presumed to have reenacted the language of section 261 so often without intending to give it some meaningful effect. Moreover, judicial opinions following the enactment of the Sherman Act appear to assume

25 Act of Mar. 3, 1897, ch. 391, §5, 29 Stat. 693.

26 Act of Aug. 18, 1941, ch. 370, 55 Stat. 634.

2735 U.S.C. §261 (1964).

28 Baxter 351.

2935 U.S.C. $\$ 261$ (1964). 
the validity of exclusive territorial assignments, ${ }^{30}$ and the final congressional reaffirmation of section 261 followed those decisions. Congress' choice in the 1951 amendment not to deny the validity of those judicial assumptions, but, instead, to alter the statutory language to make the authorization even more palpable, indicates that Congress has authorized the practice.

Another basic flaw in Professor Baxter's construction of section 261 is his failure to recognize that its conflict with the Sherman Act is merely symptomatic of the larger conflict between the policy of the antitrust laws and that of the patent laws. Faced with this conflict between two accepted economic goals and the failure of Congress to consider the conflict when enacting either statute, courts should analyze the strength of the underlying policies, measuring the relative cost to the patent policy if the Sherman Act were held to repeal section 261 against the damage to the competitive philosophy of the antitrust laws if section 261 were held to permit exclusive territorial assignments. Professor Baxter's chief concern is that exclusive territorial rights may be abused by those who agree to pay royalties to a patentee although they know the patent to be worthless except as a tool to effectuate market division. ${ }^{31}$ For that reason he advocates proscription of the practice. $^{32}$ Similarly, other critics suggest severe restrictions. ${ }^{33}$ Thus the potential abuse, not the general use, of exclusive assignments has prompted criticism. The suggested restrictions therefore do not represent an attempt to conform section 261 to the Sherman Act-a proper purpose-but an attempt to limit acts authorized by section 261 in order to prevent the possibility of antitrust violations. But until such a danger has been proved realistic, and until less drastic remedies have been exhausted, exclusive territorial assignments should not-under existing antitrust law-be proscribed or so severely limited. Proscription would not comport with the assumption of their critics ${ }^{34}$ that territorial restrictions serve a valuable function insofar as they encourage capital investment, the development of specialized production techniques, and wider dispersion of the benefits of the patent. ${ }^{35}$ As

30 See United States v. General Elec. Co., 272 U.S. 476, 489 (1926); Crown Die \& Tool Co. v. Nye Tool \& Mach. Works, 261 U.S. 24, 37 (1923) (quoting Waterman v. Mackenzie, 138 U.S. 252, 255 (1891)).

31 Baxter 347.

$32 I d$.

33 See Gibbons 903; Turner 471-74.

34 See, e.g., TASK ForCe RePoRT 11; Gibbons 895; Turner 470-74.

35 See text accompanying notes $62-71$ infra. 
Justice Frankfurter stated in his dissenting opinion in International Salt Co. v. United States: ${ }^{36}$

[T] he law also respects the wisdom of not burning even part of a house in order to roast a pig. Ordinarily, therefore, when acts are found to have been done in violation of antitrust legislation, restraint of such acts in the future is the adequate relief. ${ }^{37}$

Interpretation of the Sherman Act as nullifying section 261 would destroy an important part of the patent law structure in order to eliminate a small and speculative danger.

Finally, Professor Baxter notes: "On its face [section 261] leaves untouched the validity of territorial restrictions in licenses " 38 On that basis alone he implies that section 261 plays no role in determining the applicability of the Sherman Act to such licenses. ${ }^{39} \mathrm{He}$ would interpret section 261 to authorize assignments of exclusive territorial rights, but would add the proviso that the assignee in turn be compelled to grant licenses equivalent in scope to the assignment to anyone desiring comparable rights. Similarly, he would allow a patentee to issue territorially restricted licenses, but after the first license would compel the patentee to license any other applicant desiring comparable rights. ${ }^{40}$ By this distinction between assignments and licenses he purports to give meaning to the provision entirely compatible with both the antitrust policy of the Sherman Act and the legislative purpose imbued in section 261. But this distinction satisfies neither the legislative purpose nor economic reality. As indicated earlier, the purpose of section 261 was to distinguish between patent assignments and patent licenses. Prior to enactment of that section it was questionable whether a patentee who granted exclusive territorial rights transferred a sufficient interest to constitute an assignment or whether such a narrow transfer could constitute only a license; that is, it was clear that at least a license was permissible, but not whether an assignment of that nature was permissible. Section 261 made clear that patentees could make exclusive territorial assignments as well as

36332 U.S. 392 (1947).

37 Id. at 403.

38 Baxter 352.

39 Id. 351-52.

40 Id. 351-52, 357. 
exclusive territorial licenses. ${ }^{41}$ Nor would any economic purpose be served by the distinction between licenses and assignments as those terms are commonly understood. The difference between the two forms of transfer is primarily one of legal consequences, with no relevant underlying economic consequences. In each case a single grantee may be the only one permitted to practice the patent within the territory, and he may practice it to the full extent of the lawful monopoly. The only limitations on a licensee concern his flexibility and his ability to recover from infringers. Under these circumstances, an exclusive territorial licensee is economically equivalent to a territorial assignee, and should be treated as equivalent-if congressional policy permits the one, it clearly should permit the other. ${ }^{ \pm 2}$ Professor Baxter's imposition on the assignee of an exclusive territorial right of the duty to grant licenses within his territory also lacks reason: this duty would undercut the economic motive for acquiring an exclusive assignment of patent rights.

The foregoing analysis, however, only demonstrates that exclusive territorial assignments and licenses are not proscribed by existing laws. ${ }^{43}$ The wisdom of amending the patent laws to proscribe such practices, as the Task Force on Antitrust Policy recommended, remains to be examined.

\section{A Reexamination of the Desirability of Exclusive TERRITORIAL RIGHTS}

Four reasons have been offered for patentees' use of exclusive territorial grants: ${ }^{44}$ (1) The patentee may be attempting to differentiate prices in regions with different demand characteristics or different costs of production. ${ }^{45}$ (2) The patentee may be yielding to

41 Cf. Waterman v. Mackenzie, 138 U.S. 252 (1890):

The patentee or his assigns may, by instrument in writing, assign, grant and convey, either, 1st, the whole patent, comprising the exclusive right to make, use and vend the invention throughout the United States; or, $2 \mathrm{~d}$, an undivided part or share of that exclusive right; or, $3 \mathrm{~d}$, the exclusive right under the patent within and throughout a specified part of the United States. . . Any assignnent or transfer, short of one of these, is a mere license, giving the licensee no title in the patent, and no right to sue at law in his own name for an infringement.

$I d$, at 255 (emphasis added) ; accord, 4 A. WALKER, supra note 1 , at $\$ 343$, at 376-77; Ellis, Validity of Doctrine That a Full Exchusive License Is in Fact an Assignment, 36 J. PAt. OFF. Soc'y 643 (1954).

42 See Gibbons 898.

43 "Proscribed" of course includes limitations, such as those suggested by Professor Gibbons, which are so severe as to emasculate $\$ 261$.

44 In keeping with the foregoing discussion, the term "grants" will include assignments and licenses, and the term "territorial licensing" will include territorial assignments.

45 See Baxter 347. 
the "unrecoverable sunk cost" argument of prospective licensees: the promotional or developmental costs necessary to utilize the invention are so great that the license will be worthless unless the initial licensee in a particular region is given the opportunity to earn sufficient monopoly profits to recover those costs before additional licensees are permitted to benefit from his initial investment. ${ }^{46}$ (3) The patentee may be attempting to induce entities with risk-taking resources to assume or share the risk involved in developing or marketing his invention. $^{47}$ (4) The patentee may be aiding some or all of the companies in a particular industry to effectuate horizontal market division. ${ }^{48}$

Although other reasons may motivate the practice, only these four appear to offer a reasonable possibility of economic advantage to patentees. Unfortunately, no empirical data are available to indicate which, if any, of these reasons in fact explains the practice. While exclusive territorial grants may be used at times without any sound reason, permitting this practice is unjustifiable because neither the patentee nor the public benefits from a misallocation of resources favoring the grantee. Therefore, the following analysis will be limited to the above four reasons for using exclusive territorial grants. The desirability of each goal and the effectiveness and potential harmfulness of this manner of achieving it, as well as the availability of substitute means, will be examined.

\section{A. Price Differentiation}

A patentee engages in price differentiation ${ }^{49}$ by varying the royalties he charges his licensees in accordance with their respective purchaser demand functions. The appeal that such a system holds for a patentee can be demonstrated by a brief example: Suppose that $P$ holds a patent for air conditioners. Suppose further that the cost of producing air conditioners does not depend upon the location of the plant. Suppose finally that the demand for air conditioners is such that many Arizona residents will pay at least five hundred dollars to own one, but that few Oregon residents will pay more than three hundred dollars for the same item. Clearly if $\mathrm{P}$ manufactures and sells his product at the same price in both states, he will fail to maximize

46 See Gibbons 895; Turner 462.

47 See Gibbons 895 ; Turner 462.

48 See Baxter 347; Gibbons 902-03; Turner 471, 474.

49 In certain respects price differentiation closely resembles traditional price discrimination. As. Professor Baxter has shown at length, however, a precise definition of price discrimination must exclude the type of differentiation with which this Article is concerned. See Baxter 280-99. 
his profits. Similarly, if he licenses others to manufacture and sell, he will reap greater profits by charging higher royalties in Arizona than in Oregon. By differentiating his royalty charge, the patentee attempts to maximize his profit within each geographical market. ${ }^{50}$

Exclusive territorial licensing contains two levels of restriction: the territorial restriction, by means of which the patentee establishes territories but does not necessarily restrict the number of licensees in each geographical region, and the exclusivity restriction, by means of which only one license is granted in each region. Therefore, as a method for testing the validity of the claim that territorially exclusive restrictions aid in the program of price differentiation, the following analysis will examine first the problems a patentee encounters in using non-exclusive territorially restricted licensing to differentiate prices, and then the benefits and disadvantages he incurs by adding the exclusivity restriction.

Territorially restricted licensing can aid the patentee in establishing a price-differentiation system by preventing the "favored" licensees who pay lower royalties from selling at low prices in the territories allocated to the "disfavored" licensees. The patentee would use territorially restricted licensing to effect price differentiation and maximize his profit by charging all licensees in any given region a royalty commensurate with the demand function in their sales region. Naturally, the patentee's incentive to implement price differentiation depends upon his receiving returns greater than the administrative costs of the system, and his incentive increases as his returns rise above his costs.

50 The patentee's approach can be illustrated graphically as follows:
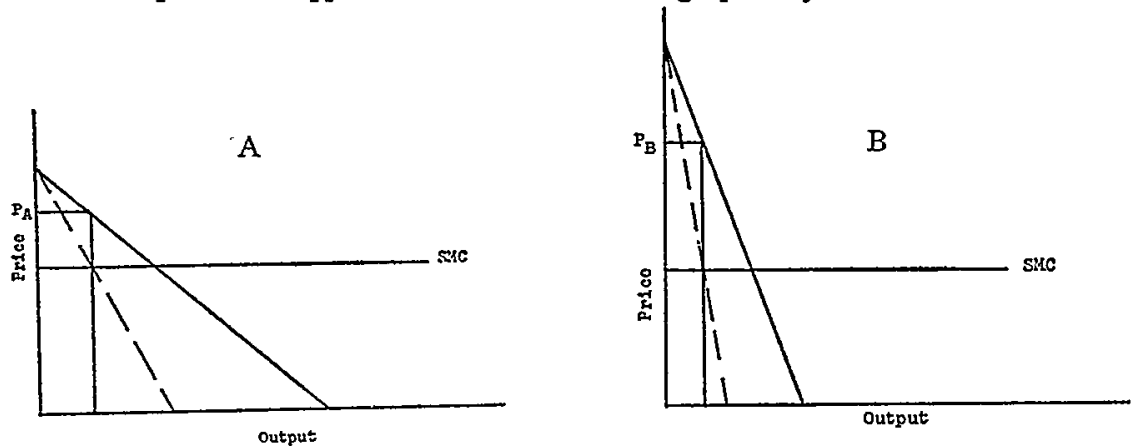

SMC (short-run marginal cost) in $A=\operatorname{SMC}$ in $B$

In both region $A$ and region $B$ the short-run marginal costs (SMC) incurred in producing the product are assumed constant and equal. The demand curve (solid line) in $A$, however, is more elastic than the demand curve (solid line) in $B$. Since a monopolist maximizes his profits by setting his price at the intersection of his short-run marginal cost curve and his marginal revenue curve (broken line) in any given market, a different maximizing price will result for $A$, where the maximizing price will be $\mathrm{P}_{\mathrm{A}}$, than for $B$, where the maximizing price will be $\mathrm{P}_{\mathrm{B}}$. See $\mathrm{R}$. Leftwich, The Price System and Resource Allocation 197-200 (3d ed. 1966). 
But several factors impair the patentee's ability to differentiate through territorially restricted licensing.

First, there are enforcement problems. The most significant of these arises from arbitrageurs-individuals who buy from licensees in a favored territory and resell in a disfavored territory. Though partially deterred by the costs inherent in their duplication of the licensee's activities, those individuals are protected from infringement actions by the established doctrine that the patentee's monopoly is "exhausted" by the first sale of his patented product. ${ }^{51}$ The patentee must also cope with "foreign customers"-individuals who reside in a disfavored territory and cross into a favored territory to make their purchases. Given adjacent territories with differing demand functions, the patentee would have to require each licensee to demand proof of each purchaser's domicile, a requirement neither easy to administer nor likely to generate consumer goodwill. Moreover, the patentee must prevent the favored licensees themselves from transporting the patented product across their designated boundaries and into less favored territories. Although such activities would breach the licensing agreements, significant regional price discrepancies are likely to evoke a certain amount of clandestine competition among licensees from different territories.

The difficulty a patentee experiences with enforcement is likely to increase with the degree of differentiation-as the price discrepancy between any two territories increases because of royalty rates, the amount of interterritorial trade will increase. Indeed, if interterritorial trade becomes sufficiently lucrative because of significant price discrepancies among the territories, the patentee's system could collapse. This enforcement problem is mitigated, of course, by the costs of transportation between the markets, but this is an independent reason militating against any need for territorial licensing rather than proof of its effectiveness. ${ }^{52}$

51 See, e.g., Keeler v. Standard Folding Bed Co., 157 U.S. 659 (1895); Adams v. Burke, 84 U.S. (17 Wall.) 453 (1873).

52 Professor Gibbons asserts:

Domestic territorial restrictions typically are employed where the licensed activity has only a limited geographic market. Where the restriction concerns a product, the transportation cost of the product is usually high compared to its price by volume, with the result that its "natural" market is local or regional. Where the process or product licensed involves a service activity, the demand for the service is usually local. Because the market normally has "natural" territorial limitations, effective exploitation of the patent requires that the activity be practiced at several or a number of places.

Gibbons, supra note 2, at 894-95. However, to the extent that Professor Gibbons' observations are accurate, the patentee need not impose legal restrictions on his various territorial licensees if he seeks to differentiate prices; the natural barriers to interterritorial competition should be sufficiently high to allow him to establish a differential system. Thus, in the great majority of cases the magnitude of enforcement problems varies inversely with the height of natural barriers. In short, for a 
A second problem arises if the patented invention is valuable primarily because it reduces the cost of producing an old product. The producers must be induced to switch from their old production methods if the patentee is to establish a profitable price-differentiation scheme through territorially restricted licensing. This problem constitutes a substantial deterrent to effective price differentiation through territorially restricted licensing because an existing competitive end-product market imposes a ceiling on the price licensees can charge, and an existing monopolistic end-product market, unless destroyed, will prevent production of the quantity of goods yielding maximum royalties.

In every case, however, the first impediment is the difficulty of determining when and where identifiable, distinct markets exist that are conducive to price differentiation. If the patented product or process merely reduces the cost of producing an old product, the patentee's problems with the end-product demand may not be great because he faces a preestablished market. But if the patent is on a new or improved end product, the profit-maximizing royalty rate is difficult to determine because the demand function is unknown. Obviously, trying to anticipate demand functions and production costs in several regions compounds the difficulty.

In summary, territorial restrictions alone are unlikely to effect profitable price differentiation. Added administrative costs, enforcement problems, resistance to changes in production methods, and difficulties in accumulating the necessary economic data all coalesce to force this conclusion.

If the patentee grants exclusive territorial licenses, he may more successfully and cheaply solve one aspect of his enforcement problems-preventing licensees from engaging in clandestine interterritorial competition-because he will have fewer licensees to watch. However, none of the other impediments to effective price differentiation would be affected.

Moreover, it is generally in a patentee's best interest to license all those desiring licenses in a particular territory. ${ }^{53}$ If the patentee were to manufacture and sell the end product of his invention rather than to grant licenses, he would maximize profits by selling at a price and output determined by the intersection of his marginal revenue curve and his short-run marginal cost curve. ${ }^{54} \mathrm{He}$ could also reap maximum profits by granting sufficient licenses to ensure that competitive pricing

patentee attempting to enforce territorially restricted licensing in order to achieve price differentiation, the incremental effect of such licensing will be reduced by either its redundancy or ineffectiveness, or a combination of the two.

53 See Turner, supra note 2 , at 462, 465-69.

54 See R. LEFTWICH, supra note 50, at 197-200. 
conditions prevail at the retail level and charging a royalty equal to the difference between his licensees' prices for the quantity they would produce if operating as monopolists free of the royalty and their shortrun marginal costs. Under those conditions, each licensee would view his royalty obligation as an added cost of production, and the market price of the end product would equal the higher cost of production incurred by the licensees.

If the patentee grants an exclusive license, however, he places the licensee in a monopoly position in the retail market for the end product. The licensee will therefore seek to sell at a price and output determined by the intersection of his marginal revenue curve and his short-run marginal cost curve, including in his cost the royalty he must pay the patentee.

This can be illustrated graphically as follows:

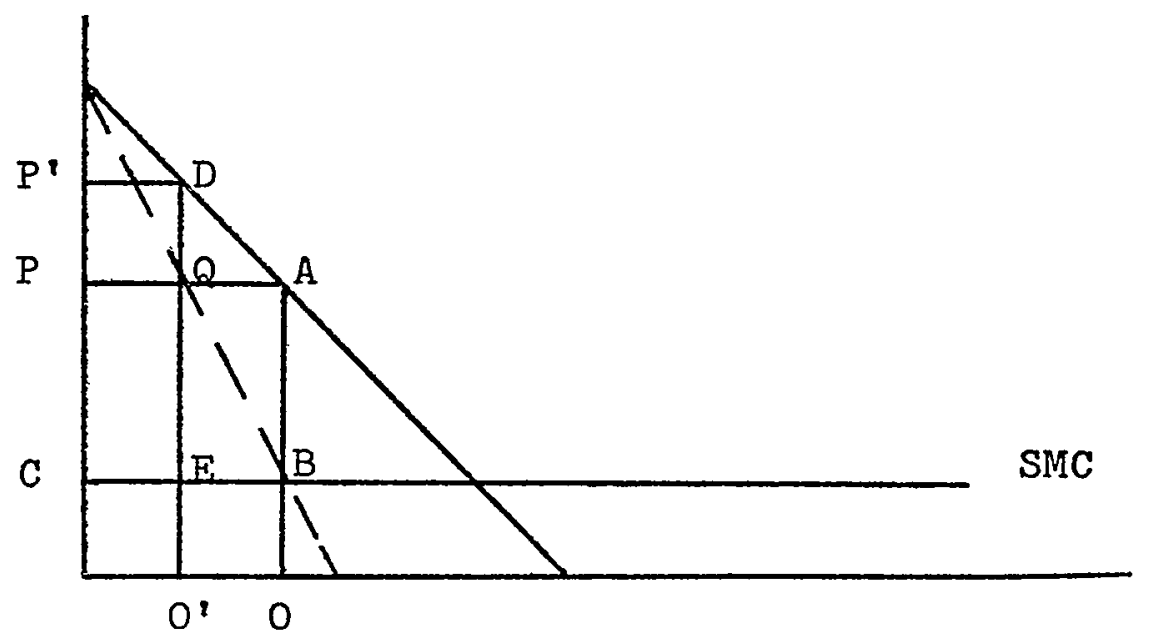

If the end-product demand curve is DA, the patentee would like the price to be $P$ and the royalty payments to him to be the area enclosed within PABC; this enables him to squeeze the full monopoly benefit from the licensee, who will not produce more because he would be compelled to lower his price below his costs to dispose of the product. At that royalty rate (P-C), however, the licensee's short-run marginal cost curve rises from SMC to PA. To maximize his own profits, the exclusive licensee will sell at $P^{\prime},{ }^{55}$ reducing the output to $O^{\prime}$ and the royalty payments to $\mathrm{PQEC}$, an area smaller than $\mathrm{PABC}{ }^{56}$ The patentee will lose the difference between the two unless he can control the price at which his licensees sell. 
Though the right of a patentee to fix the prices at which his licensees sell was upheld in United States v. General Electric Co., ${ }^{57}$ the continuing validity of that case is questionable.58 Moreover, when the patentee's invention is not an end product-for instance, when the invention is only part of a complex machine-courts have generally prohibited restrictions on pricing and distribution of the end product by the patentee, holding such restrictions to be unlawful "extensions" of the patent. ${ }^{58}$

Making territorial licenses exclusive therefore adds little to the patentee's ability to establish a profitable price differentiating system and can often detract from such a system. Thus, if other reasons exist to proscribe exclusive territorial licensing, the desire of some patentees to differentiate prices on a territorial basis should not be considered a valid objection to proscribing exclusive licensing.

\section{B. Initial Investment Costs}

Initial investment costs- those accruing prior to the commencement of manufacturing and selling-can consist of promotional costs, development costs, capital investments, or any combination of these three which the licensee attempting to market the invention incurs. The initial investment costs which might induce a patentee to grant an exclusive territorial license are those borne only by an initial licensee in a particular region-only if the initial developer incurs costs which redound to the benefit of subsequent licensees will the patentee be compelled to induce development of the invention by compensating the developer differently from these later licensees. ${ }^{60}$

Consider, for example, an invention which is valuable only if certain expenditures are made to improve it. Suppose relative certainty that the final product can be developed after a reasonable amount of effort, that the demand for the final product can be estimated, and that the improvements are not patentable. ${ }^{61}$ Under these circumstances, the licensee will seek a royalty agreement permitting him to recover his initial investment and sell the final product at a price allowing him a reasonable rate of return. Naturally, this licensee fears that subsequent licensees will have lower initial development costs because of external economies generated

57272 U.S. 476 (1926).

68 See P. Areeda, Antitrust Analysis 339 (1967). See also United States v. Line Material Co., 333 U.S. 287, 315-21 (1948) (Douglas, J., concurring).

59 See, e.g., United States v. General Elec. Co., 82 F. Supp. 753 (D.N.J. 1949).

60 Subsequent licensees will benefit from the developmental efforts of the initial licensee either if technology flows freely within the industry or if the end product effectively discloses the fruits of the developer's labor.

61 Although no-risk developmental ventures are probably a rarity, of. Turner, supra note 2 , at 462 , the investment costs argument should be confronted. 
by his expenditures and will consequently be able to undersell him in the marketplace.

To insure that the initial licensee receives a reasonable return on his investment, the patentee may grant an exclusive territorial license enabling the licensee to receive monopoly profits in his territory for a period long enough to amortize his initial investment costs. But an exclusive territorial license may be unnecessary to the recovery of those costs. The patentee could simply pay the initial licensee a lump sum equal to the unrecoverable costs attributable to special efforts in developing the invention, and then charge the same royalty to all licensees. Alternatively, the patentee could give the initial licensee preferential royalty treatment to the extent his initial investment costs exceed those of subsequent licensees.

The most obvious reason that a patentee would grant an exclusive license is that he lacks the capital necessary to initiate the venture. Assuming, however, that the marketability of the end product is assured, either the patentee-or if the patentee is not well established, a licensee with a more solid financial structure or better credit ratingshould be able to find a source of investment capital without resorting to exclusive territorial licensing. Thus, because the patentee has alternative means of compensating the initial licensee for his sunk cost investment when little risk is involved, exclusive territorial licensing is unnecessary to encourage licensees to develop the invention. If other reasons exist for proscribing the practice, the initial investment cost argument should not justify its retention.

\section{Risk Compensation}

Two general types of risk may be involved in the development or promotion of an invention: first, the risk that the invention as patented can never be developed into a valuable product; second, the risk that the public will reject the product-in spite of its social utility, and after a large sum has been spent in developing and preparing to manufacture and sell the product. Of course, the risk may involve a combination of these two forms.

As an example of the first type of risk, suppose the patentee has invented a process which cures cancer in rats and involves a certain strain of bacteria. Suppose further that the only value of the invention in its present state is the potential application of a similar process to cure cancer in humans if thousands of bacterial strains are substituted for the one used in the patented process. Such research will involve substantial costs and, even then, success will be uncertain. The patentee 
in this situation does not have access to the many sources of investment capital available in the negligible-risk cases discussed above because here the product may never be developed, and investors will be unwilling to extend credit with no more security than the mere possibility of success. Even if they could borrow the money, many patentees would be reluctant to incur personal obligations to the extent necessary to guarantee the repayment of the loans. The patentee, unwilling or unable to develop the invention himself, must entice a prospective licensee to take or share the risk. Obviously, potential rewards greater than the going rate of return must be promised the prospective licensee to lure him into the venture.

One inducement the patentee can offer is an exclusive territorial license. The territory need not reflect any particular market, but its size and composition should be determined only by the relative bargaining strength of the parties. The patentee has the basic invention; the prospective licensee has the risk-taking resources. The only question is how much the patentee must give the prospective licensee to induce him to participate. Furthermore, the patentee should have to grant only one such license in order to have his invention developed. Once the developmental problems are solved by the initial licensee, the patentee can make the necessary information available to any number of licensees outside the exclusive territory reserved for the initial licensee.

The Task Force and Professors Turner and Gibbons recognize the valuable role of exclusive territorial licensing in inducing development of high-risk inventions. Each suggests that when the risk involved necessitates additional licensing flexibility for the patentee, exclusive territorial grants be excepted from proscription. ${ }^{62}$

Professor Gibbons proposes substantial limitations on the use of the device even for encouraging risk-taking. However, in his first suggested constraint, that "[a]ny exemption should be limited to a short development period," ${ }^{63}$ he fails to appreciate the fundamental reason for permitting the exemption: the patentee needs the services of reluctant developers and must provide sufficient incentive. In this respect, the length of the licensing period, like the size of the territory, can be varied with the degree of risk involved to determine the size of the potential reward available to the prospective licensee. Restricting the permissible licensing period would only force patentees to grant larger exclusive territories; but the long-range threat to competition

62 See TASK Force Report, supra note 5, at 11; Gibbons, supra note 2, at 895; Turner, supra note 2 , at 462 .

63 Gibbons, supra note 2 , at 895 . 
should be no more serious if a small territory is monopolized for seventeen years than if a larger territory is monopolized for fewer years.

The arbitary nature of Professor Gibbons' second suggested restriction, limiting use of the device to "patented technology with a high degree of novelty," "64 is readily apparent-as are its inherent administrative problems. Indeed, the patent office has a difficult task in determining what is "novel" under the patent laws presently in existence; adding the further limitation of "a high degree" can only compound that problem.

Professor Gibbons proposes thirdly:

Limitation of the size of the licensee, geared to the capital requirements of the particular industry, should also be required, because a major reason for the exemption is encouraging small businesses which have limited power to attract development capital. ${ }^{65}$

This suggestion, too, presents obvious administrative problems and ignores the rationale for the use of the device. Exclusive territorial licenses are justifiable to encourage the introduction and development of patented technology by inducing some prospective licensee to take the necessary risk. In many cases the small businesses "which have limited power to attract development capital" " will, like the patentee, be either unable to acquire the capital required to take the risk or unwilling to gamble their very existence on one long shot. Therefore, the patentee should not be foreclosed from seeking help from larger entities. Furthermore, without the restriction recommended by Professor Gibbons, patentees in need of a development risk-taker will not necessarily run to the nearest corporate giant.

Professor Gibbons suggests one other restriction:

The exemption should not be available to protect restrictions on distribution by the licensees, for these should be illegal per se; it should apply only to the issuance of exclusive territorial licenses by the patentee. Territorial protection of making and using the invention should be an adequate inducement to prospective licensees without the addition of a monopoly to sell in the territory, which would involve risks of a collusive cartel. $^{67}$

This rule arbitrarily discriminates against all prospective licensees operating in territories without convenient natural barriers. If the

$64 I d$.

$65 I d$.

$60 I d$.

67 Id. 
manufacturer-seller licensed by the patentee under Professor Gibbons' rule to make and use the patented invention happens to have high natural barriers to protect his territory, he will in fact have the monopoly on sales feared by Professor Gibbons. If, however, the licensee is not so blessed, licensees in other territories will be easily able to compete in that territory, and an exclusive license applying only to manufacture and use will be worth no more than a nonexclusive license. Not only does this rule arbitrarily favor one group of developers, but it also defeats the very purpose for which the device is permitted; few licensees will be lured into a high-risk venture with the promise of an exclusive license to manufacture in a territory into which the end product can be shipped with ease from adjacent territories.

Although Professor Turner and the Task Force also recognize the role of exclusive territorial licensing in encouraging risk-taking, they suggest its prohibition unless the patentee can prove to the satisfaction of an examining body-perhaps the patent office-that exclusivity is "necessary to anyone's undertaking exploitation of the patent in that territory." 68 This is a substantial improvement over an outright proscription, but evidentiary problems might prevent many patentees from convincing the examining body that exclusivity is truly necessary. In those cases, the patentees would be left with the choice of abandoning development altogether or assigning the entire patent to one purchaser. To the extent that the latter course is followed, national monopolies will replace the limited monopolies that would otherwise have appeared.

Professor Turner's further suggestion, that the rule should require the patentee to show the need for exclusivity "for a reasonable period of time," 69 poses even greater problems for the patentee. If this proposal implies that the examiners should have the authority to determine the life of the license-with a maximum life equal to the life of the patent-and, perhaps, to set limits on the size of the territory or territories, the patent examiner will be required to make judgments of a business nature which are beyond his competence. The bargaining between the patentee and his prospective licensees would also be affected both before and after the patentee approaches the examiners for permission to employ exclusive territorial licensing, and the patentee might even find himself forced to contract with a licensee who satisfies the mandate of the examiners rather than with the licensee or licensees with whom he would prefer to associate.

68 Turner, supra note 2, at 474; see TASK FORCE REPORT, supra note 5, at 22.

69 Turner, supra note 2 , at 462 . 
The second type of risk which might cause the patentee to grant exclusive territorial licenses is promotional risk-the risk that the public may reject the invention after substantial promotional investment (such as advertising) or capital investment (such as expensive manufacturing machinery). ${ }^{70}$ The foregoing discussion of developmental risk applies in general to promotional risk, but the two differ in certain respects.

First, whereas developmental risk might inhere in a patent on a new product, a new subproduct, or a new process, promotional risk should not significantly affect the inventor of either a new subproduct or a new process. This is because the largest promotional costs are those incurred in appeals to the taste and needs of the general publicappeals not necessary for these types of inventions. For example, the cost of advertising on television and in other communications media can be exorbitant. If the invention merely lowers production costs or constitutes a more reliable part in a complex piece of equipment the promotional expenses incurred will generally be negligible. Existing promotional methods, such as periodic visits to manufacturers from salesmen, often suffice to introduce a new cost-saving device; and existing general advertising programs can usually be modified to inform the general public of newly lowered retail prices or of higher quality parts. Therefore, with regard to a new subproduct or process, promotional risk-taking is little influenced by the resolution of the question whether to allow exclusive territorial licensing.

But whereas a patentee will rarely need to grant more than one exclusive territorial license to induce a prospective licensee to develop the invention, ${ }^{71}$ patentees may more frequently need to grant several such licenses to market the invention on a nationwide basis. Special incentives may be needed in each region because demand for any given product may vary greatly from region to region. Successful marketing of the invention in Arizona may not be sufficient to induce a prospective licensee in Alaska to invest promotional and investment capital in his region. Thus, although the developmental risk is dispelled for all future licensees once an invention has been technologically perfected, the patentee may need promotional risk-takers in each new territory in which he wishes to market his invention.

Extensive use of exclusive territorial licensing to induce prospective licensees to take promotional risks is partly obviated by the prob-

70 Consider, for instance, the problem faced by the patentee of three-dimensional television. Although the invention would probably have considerable intrinsic appeal for the public, the cost or inconvenience of any necessary special equipment might make the invention a commercial failure.

71 See text preceding note 62 , sitpra. 
ability that the amounts involved in testing the marketability of an invention for a localized region are relatively small. That promotional risks are often small enough to be met without special treatment is illustrated by the willingness of manufacturers, distributors, and retailers in many industries to introduce new products without patent protection and potential monopoly profits: "new" kitchen cleansers, facial soaps, toothpastes, detergents, and clothing styles appear daily, yet all require significant promotional investment. If such risk-takers are available for unpatented new products, it seems safe to assume that risk-takers will generally be available for patented new products, particularly after the patented invention has been successfully marketed in one or more test territories. Insofar as there may be exceptions to this rule, the necessary exclusive territorial grants could be allowed after adequate proof and subject to the discretion of patent authorities.

Thus, exclusive territorial grants encourage both developmental and promotional risk-taking, enabling a patentee to realize the full value of his invention and the public to benefit from use of the patented product. Unless this type of grant results uniformly in anticompetitive practices, the patentee should be permitted as a matter of course to grant one, and only one, exclusive territorial license or assignment. Allowing more than one would aid neither the public nor, in most instances, the patentee.

\section{Collusive Cartels}

The spectre causing Professors Baxter, Gibbons, and Turner, and the Task Force to suggest either proscription or severe limitation of exclusive territorial licensing is the collusive cartel. ${ }^{72}$ Professor Gibbons describes an admittedly "extreme" example of potential cartelization as follows:

The situation . . . is where the patentee and licensee are the only firms in the industry, there is substantial competition between them in Midwest markets, the patent is of doubtful validity and of small commercial significance even if valid. Further, the license is exclusive and, after it has been executed, competition between the parties ceases not only as to the product manufacturd [sic] by the process, which the licensee does not even employ, but as to the entire range of associated products that both parties sell and that are not expressly affected by the restriction. ${ }^{73}$

72 See TASK FORCE REPORT, supra note 5, at 11; Baxter, supra note 2, at 347; Gibbons, supra note 2, at 903; Turner, supra note 2, at 471, 474 .

73 Gibbons, supra note 2, at 902 . 
The solution proposed by Professor Turner and the Task Force and the accompanying problems have already been discussed. ${ }^{74}$ Professor Baxter's solution is to require any patentee who licenses one person to license all others on the same terms. ${ }^{75}$ This would permit territorially restricted licensing with an unlimited number of licensees in each region, but not exclusive territorial licensing with only one licensee per region. Professor Gibbons suggests that

where the competition that is expressly restrained by the territorial limitation on the licensee concerns an activity . . . that is not completely covered by the licensed patent, the restriction should be considered illegal per se and a misuse of the patent. ${ }^{76}$

Before adopting either of the suggested restrictions, however, the probability that such cartels would result from exclusive territorial grants should be established. As Professor Gibbons indicates, ${ }^{77}$ and as reported cases concerning such cartels show, ${ }^{78}$ the prerequisites for this type of profitable cartel often make it highly visible to antitrust prosecutors. If the patent is truly valuable and applicable to the industry in question, the patentee should be unwilling to assist the conspiracy, for, as already noted, ${ }^{79}$ patentees will avoid issuing exclusive licenses when the invention is valuable. ${ }^{80}$ Hence, to be a device for cartelization, the patent must be of little or no value to the industry, neither cutting costs of production nor creating a larger market. Further, in order to prevent existing, rather than prospective, producers from contesting the arrangement or destroying its effectiveness through competition, all of them must be included in the cartel, automatically restricting use of the device to cases approximating Professor Gibbons' "extreme" example of two national producers. When a highly concentrated industry is engaged in horizontal market division on the basis of exclusive territorial licenses, the patent itself, the applicability of the patent to the industry, the actual use or non-use of the patent, and each step leading to the decision to adopt the patented product or process will invite close scrutiny. And if, as in Professor Gibbons' example, the conspirators begin to extend the market division to

74 See text accompanying notes 68-69 supra.

75 See Baxter, supra note 2 , at 347.

76 Gibbons, supra note 2, at 903.

77 See id. 902.

78 See, e.g. United States v. National Lead Co., 63 F. Supp. 513 (S.D.N.Y. 1945), aff'd, 332 U.S. 319 (1947).

79 See text accompanying notes 53-56 supra.

80 Naturally, the patentee holding a valuable patent may be compelled to grant an exclusive license to compensate a risk-taking licensee. See text accompanying notes $62-71$ supra. 
products unrelated to the invention, prosecution under the Sherman Act is likely to follow.

Furthermore, as with any monopoly situation, if the patent is of negligible value to the industry in question and the extant producers adopt it only to raise prices, new entrants seeking a share of the monopoly profits will be encouraged to compete without using the cartel-effectuating invention. Entry may be difficult when several other important patents relating to a complex end product are held by extant producers, but their refusal to grant licenses to new entrants while licensing each other will provide further evidence of the cartel. Since patentees will rarely have to grant more than one exclusive territorial license restricting distribution in order to obtain developmental risktakers, ${ }^{81}$ and since such grants are rarely necessary or useful for other reasons, the mere existence of a system in which several major entities in a given industry hold exclusive territorial licenses to the same patented invention will provide substantial evidence that a cartel exists.

Because the desirability of ensuring rapid adoption of patented technology calls for the use of exclusive territorial licensing, and because the major evil perceived by the Task Force and Professors Baxter and Turner can be eliminated by applying existing antitrust laws, exclusive territorial grants should not be proscribed solely on the basis of a general fear, unsupported by empirical data, of extensive collusion.

Professor Gibbons' suggestion that the device should be illegal per se when "the competition that is expressly restrained . . . concerns an activity . . . that is not completely covered by the licensed patent" $\$ 2$ is a somewhat narrower restriction than that suggested by Professor Baxter and the Task Force. If read literally, the Gibbons rule is unobjectionable, for it merely proscribes express restrictions on nonpatented items. That a stereo system may contain a certain type of patented speaker is no reason to permit the patentee to restrain stereo manufacturers from transporting and selling all stereo systems, whether they contain the patented item or not.

However, if, as Professor Gibbons' examples indicate, he meant to preclude a patentee from restricting the distribution of his invention if it is physically incorporated in some larger item, the rule is needlessly arbitrary. Under such a rule, the inventor of a completely new end product could grant exclusive territorial licenses, but no other patentee could do so. This rule completely ignores the fact that the value of many, and probably most, patents depends upon their incor- 
poration in an unpatented end product. Like the rule suggested by Professors Baxter and Turner and the Task Force, it fails to consider the visibility of any cartel based upon horizontal market division through use of a valueless patent. Consequently, the Gibbons rule should also be rejected.

\section{A COMPROMISE}

Although the foregoing discussion indicates that exclusive territorial licensing should be permitted, its limited utility and the added burden on the judiciary resulting from a permissive approach suggest the advisability of an administratively simple compromise. The compromise proposed by the Task Force and Professor Turner is neither administratively simple nor likely to permit use of exclusive territorial licensing, even when necessary; ${ }^{83}$ and the proposal of Professor Gibbons is rife with difficulties. ${ }^{84}$ But a workable compromise which should prove satisfactory to both critics and proponents of exclusive territorial licensing is available: A patentee should be allowed to grant one exclusive territorial license, the size and composition of the territory and the length of the exclusive period to be determined by the bargaining process. Additional exclusive grants should be allowed if made pursuant to the proposal of the Task Force and Professor Turner-by application to an administrative official. This rule should satisfy proponents of exclusive territorial licenses, because exclusive territorial licensing is rarely needed except to encourage entrepreneurial investment of risk capital for development purposes, and a patentee should rarely need to grant more than one exclusive license to promote development of a risky invention. To the extent that localized promotional problems require additional exclusive grants the patentee could be allowed to apply for special permission to use them upon a demonstration of necessity, even though some patentees might be discouraged from doing so by the burden of proof.

This rule should satisfy Professors Baxter, Turner, and Gibbons, and the Task Force, because collusive cartels effectuated by a network of regional monopolies will be avoided by permitting only one exclusive license. Indeed, other producers, extant and potential, could still freely sell in the sole exclusive territory products made without employing the invention; and the exclusive licensee still faces the problem of arbitrage discussed above. ${ }^{85}$ Finally, the patentee's dis-

83 See text accompanying notes $68-69$ supra.

84 See text accompanying notes 63-67 supra.

85 See text accompanying note 51 supra. 
incentive to grant an exclusive license unless absolutely necessary limits abuse or extensive use of exclusive territorial grants.

One apparent drawback to this rule is that it permits the sole exclusive licensee to develop a consumer preference for his product in his region during the life of the license. But this consumer preference should have only limited impact on the competitive situation following expiration of the exclusive license. Licensees in adjoining regions will be selling the same type of product, will be free to compete in the exclusive territory using noninfringing products, and will have a strong incentive to enter the exclusive territory once the exclusive license expires. Moreover, a patentee could assign his entire patent, ${ }^{86}$ and the consequences flowing from the assignment of one limited territory would undoubtedly be less serious.

This limitation on the patentee's present legal right to grant exclusive territorial assignments and licenses under section 261 of the Patent Act would permit him to compensate a risk-taking licensee for developing the patent without encouraging the formation of cartels as feared by Professors Baxter, Gibbons, and Turner, and by the White House Task Force on Antitrust Policy. Implementation of the rule suggested in this Article will minimize the potential conflict between the antitrust laws and the Patent Act, permitting a reasonable return to inventors within the framework of the competitive system.

86 See 35 U.S.C. $\$ 261$ (1964), which states in part: "[P]atents . . . shall be assignable in law . . " Professor Baxter's critical analysis of the portion of section 261 authorizing exclusive territorial assignments is inapplicable to this phrase, for the problem of defining the scope of assignable rights as opposed to licensable rights is absent.

Professor Turner, however, has suggested that the assignability of patents should be limited in instances where the patent to be assigned constitutes an "asset" within the meaning of the Clayton Act:

At the outset, I shall simply assert categorically that Section 7 of the Clayton Act-which prohibits the acquisition of all or any part of the assets of a corporation where the effect may be substantially to lessen competition or tend to create a monopoly-applies to the acquisition of either a patent or an exclusive license. . . .

If established section 7 principles are to be applied, the statute would be interpreted to prohibit any company from acquiring a patent or an exclusive license of [significant competitive] importance ....

Turner, supra note 2 , at 460 . But even that limitation would not impede the effectiveness of the proposed compromise, for it would effectively permit exclusive licensing when a high developmental or, on rare occasions, marketing risk exists. In such instances, the large acquiring corporation would not be acquiring an asset of recognized great value; rather, it would be acquiring the possibility of gaining such an asset. Indeed, since the raw patent presumably cannot attract small developers, the role of the large developer is analogous to that of a company hiring a scientist to do internal research and development work for the company. 